Scott Spector

\title{
Another Zionism: Hugo Bergmann's Circumscription of Spiritual Territory
}

From the perspective of outside observers, whether sympathetic to the State of Israel or to the proto-state of Palestinian Arabs (or both), the central issue at stake in Israeli politics is condensed into a single formula: Land for Peace, or No Land for Peace. The question of such an exchange has been at the centre of debates over Zionist ideology and Near Eastern politics at least since the Israeli occupation in 1967. But the figure of land or 'territory' was obviously a central one in Zionist discourses before the 1967 war - hence the valence of the term 'Ha-Eretz Yisrael' (often translated as 'the whole land of Israel', as opposed to that circumscribed by the boundaries of the State), or the specious motto of early Zionism, 'The Land without People to the People without [a] Land'. These two examples point to a tension within early Zionism, however, in spite of the shared focus on territory: the latter smacks of the secular-nationalist and pragmatic Zionism of Theodor Herzl, the dominant strain of early Zionism, while the former links the political-territorial question to a religious legitimation rooted in the spiritual connection of the 'chosen people' to the 'promised land', to the historic borders of a lost spiritual community. No study of early Zionism could hope to explain either the Arab-Israeli conflict or contemporary inner-Israeli politics, both of which look quite different from how they looked half a century ago and more. And yet some exploration of the rhetoric of territory and spirituality in Zionist writing of the first decades of this century remains relevant to a set of problems circulating around notions of spiritual communality and territoriality. The discursive tension between the two mottos above, for instance, would appear to live on in the current struggle within Israel between so-called secular and religious Jewish citizens. As a Jerusalem graffito represents the conflict, 'The Land of Israel without [Orthodox Jewish Law] is like a Body without a Soul'.

How can intellectual history help us understand the complex mutual insinuation of figures of spirit and territory in Zionist discourse? A somewhat conventional strategy would be to trace the genealogy of contemporary Zionism from its early secular forms through its more recent appropriation by religious settlers of the West Bank and Gaza, but such a strategy necessarily privileges certain Zionisms over others, and tends to reify one set of ideas and even policies as a univocal, if shifting, Zionism. The fact that Zionism was, from its inception, not a unified ideology but a site of ideological contest is rarely examined, and even more rarely considered to be of any contemporary 
relevance. I would like here to bring close readings of an early alternative Zionism to bear on questions of spirit and territory in ways which destabilize monolithic understandings of the place of spiritual unity and territorial integrity in Zionist ideology. The locus of this alternative was early twentiethcentury Prague, where ideas promulgated by thinkers such as Martin Buber and Ahad Ha'am took on a very particular shape in the hands of young German-Jewish writers of Franz Kafka's generation. In the thought of Hugo Bergmann (1883-1975) we can recover 'spirit' and 'territory' as the woof and warp of a fabric which is neither typical nor exemplary, but which in its unreproducible historicity exposes the contingency of the way these terms are woven into Zionism.

\section{Circumscription}

Among the startling creative products to come out of the very small group of friends known in retrospect as the 'Prague Circle', Hugo Bergmann's particular brand of Zionism is all but forgotten. To be sure, historians have cited the activities and focus of his Prague Zionist student organization Bar Kochba as exemplary of a certain mark of what has been called 'cultural Zionism'. ${ }^{1}$ In spite of this recognition, Bergmann's pre-war writings on Judaism remain little known nowadays. It may be the case that this early and creative Zionism is now dated. By the end of the first world war, it slipped away from Bergmann himself, as if it could only survive in the unique and unstable environment of a Prague which itself was destined to disappear. Of course, Bergmann's Zionist commitment and activity continued throughout his long life, the last 55 years of which were spent in Jerusalem. Much of his later work can certainly be thought of in relation to his Prague experience, particularly his minority view on co-existence with the Arabs in Palestine. His role in B'rith Shalom, which advocated a single, bi-national state, is interesting in this regard, if only because Bergmann's Prague had been a shared space laden with ethnic conflict, in a multi-ethnic state that proved untenable. Nonetheless, Bergmann's thinking before 1918 is of a different mark from his post-Prague work, and it is this idiosyncratic thinking I would like to examine here.

Bergmann's fellow student Emil Utitz described the pre-war world of the German-speaking Prague Jews as 'a game preserve whose ground was always shrinking ... an iceberg which the surrounding waters slowly eroded'. ${ }^{2}$ These

1 The now less common term 'spiritual Zionism' was (significantly) used virtually interchangeably with 'cultural Zionism'. Several important references have been made to the Bar Kochba association as exemplary of a certain spiritualist tendency among Central European Zionist youth at the turn of the century, focusing especially on the influence of Martin Buber. Most important is G. Mosse, 'The Influence of the Volkish Idea on German Jewry', Germans and Jews: The Right, the Left, and the Search for a 'Third Force' in Pre-Nazi Germany (New York 1970), 77-115. Cf. idem, German Jews Beyond Judaism (Cincinnati 1985), 37-41. In this later volume Mosse mentions in passing the unique Zionism of Prague Jews Hugo Bergmann, Hans Kohn and others as 'a part of Zionist history which demands to be written', see 77. See also Paul Mendes-Flohr, Divided Passions: Jewish Intellectuals and the Experience of Modernity (Detroit 1991), 83-5.

2 Quoted in Pavel Eisner, Franz Kafka and Prague (New York 1950), 92. 
metaphors, symptomatic of German-Jewish Prague of this period, refer to a circle of territory threatened by the Bohemian nationality conflict and the accompanying expansion of hostile ideologies. They are metaphors worth preserving in our own analysis, for they are the ground of a rhetoric inseparable from the notions of territory and spirituality demarcated by the Prague Zionists.

In 1900, Prague's population consisted of 415,000 Czechs, 10,000 nonJewish Germans and 25,000 Jews. ${ }^{3}$ The legal emancipation of Jews had been in effect since mid-century, ${ }^{4}$ so that the generation before Bergmann and Utitz was weaned on a confident and unshakable commitment to what was known in Prague as 'German liberalism'. ${ }^{5}$ The fact that the metaphors of Prague as an island first appear in the post-liberal generation of the Prague Circle attests to the obstinate refusal of their parents' generation to recognize that their worldview was from the beginning out of step with the sentiments of anti-liberal German Bohemia, not to mention the Czech majority of the province. The illusion of German-liberal hegemony was artificially sustained in a city where cultural power remained in the hands of a German population, the majority of which was Jewish. Yet, the immediate effect of liberal political reform in Prague had been Czech-nationalist dominance of municipal politics. ${ }^{6}$ Faced with a burgeoning racialist volkish ideology on the one side, and a Czech nationalism which was as antisemitic as it was anti-German on the other, the generation of Hugo Bergmann was decentred - it was a post-liberal generation without access to alternatives.

In fact, we cannot really speak of the existence of a 'Prague Circle' of German-Jewish literati. The term was created by Max Brod more than half a century after its supposed existence, ${ }^{7}$ and his own agenda in historicizing it is really transparent. I have self-consciously employed the term not in order to

3 Hans Tramer, 'Prague - City of Three Peoples', Leo Baeck Institute Yearbook, 9 (1964), 305. Compare more detailed material in Gary B. Cohen, 'Jews in German Society: Prague, 1860-1914', Central European History, 10 (March 1977), 28-54.

4 Emancipation had begun in the 1840s, and by 1852 the ghetto (Judenstadt) was dismantled and the Jews were equal under law. See Ruth Kestenberg-Gladstein, Neuere Geschichte der Juden in den böhmischen Ländern, vol. 2 (Tübingen 1969).

5 I use the term which was used in contemporary texts, although the policies of the Habsburg 'German liberalism' are clearly distinct from other varieties. For the purposes of this article, we may summarize the ideology at the turn of the century as a cluster of 'democratic' principles aimed at dismantling privilege by birth and encouraging free enterprise, all under the banner of an extreme German chauvinist paternalism. The painful contradiction was glossed over by an almost religious devotion to the idea of 'culture', a discourse designed to exclude national 'minorities' which naturally outnumbered German speakers in their own provinces and in the Empire at large. The best treatment of Austro-German liberalism, providing an antidote to the misconception that its political impact was marginal or even brief, is Pieter M. Judson, Exclusive Revolutionaries: Liberal Politics, Social Experience, and National Identity in the Austrian Empire, 1848-1914 (Ann Arbor, MI 1996).

6 The most thorough discussion of the social and political dimensions of this situation is found in the pathbreaking work of Gary B. Cohen, The Politics of Ethnic Survival: Germans in Prague, 1861-1914 (Princeton 1981).

7 Max Brod, Der Prager Kreis (Stuttgart 1966). 
preserve it as a notion, but because it is apparent that the image of the 'circle' had a particular power in this context, invading the rhetoric of those both living in and talking about it. The rhetorical form of the circle has a number of functions. The first is the quality of circumscription, a gesture which at once effects a charting of inclusion and of exclusion, a dichotomy of internality and externality. Implicit in this structure also are the notions of 'centre' and 'periphery', which relate directly to the problem of the geographic and ideological positions of Prague in the context of Bohemia, the Habsburg monarchy and Judaism in exile. The deployment of 'circular' rhetoric is inseparable from metaphors of territory: ideological, spiritual and physical turf inscribed by discourses of inclusion and exclusion.

These relations are exceedingly complex in the context of Hugo Bergmann's generation of Prague Jews. The issue of identity is at the centre of a crisis of self which is at the same time a political crisis. Even the discussion of their literary products as representations of 'minority culture' is made problematic by the layers of identity which the Arab Israeli Anton Shammas, in a different context, has symbolized with the image of a babushka doll. ${ }^{8}$ The Prague German-Jewish writers were caught between identities 'outside' and 'inside' the power structure: a Jewish minority that was, in fact, a majority within the dominant German culture of Prague, or a German minority in Prague within a German-dominated Habsburg monarchy. The relations become more complex when, in seeking roots for their new-found Jewish identity, assimilated West European Jews looked expectantly eastward - and the essence of their Judaism seemed to them Slavic rather than Germanic.

At this confused moment, when no single system for understanding themselves and the world seemed adequate and no relations or identities seemed fixed, the Prague Circle generated its most original and important creative products. They take place in these charged spaces of alternation between inside and outside, belonging and not belonging, power and powerlessness, immanence and transcendence, slavery and freedom, matter and spirit. Kafka writes of the poets of his generation: "With their hind legs they stuck to the Judaism of their fathers, and with their forelegs they found no new ground. The despair over this was their inspiration.' The Prague conceptions of Zionism must be seen in light of this territorial dilemma, this tension between desires for lost and new ground.

8 'Ahmat Ha-Babushka' ['The Guilt of the Babushka'], Politika, 5-6 (February-March 1986), 44-5, and 'Al Galut V-Sifrut' ['On Exile and Literature'], Igra, 2 (1989), 67-70. Quoted in Hannan Hever, 'Hebrew in an Israeli Arab Hand: Six Miniatures on Anton Shammas's Arabesques', Cultural Critique, 7 (Fall 1987), 49.

9 Franz Kafka, Briefe 1902-1924 (New York 1958), 337. All translations where an English edition is not cited are mine. 


\begin{abstract}
Why have I become a Zionist?. . . I should almost stop wondering, and yet again and again I have to wonder why you, who . . . were my classmate for so long, do not understand my Zionism. If I saw a madman before me and he had an idée fixe, I would not laugh at him, because his idea is a piece of life for him. You think Zionism is also an 'idée fixe' of mine. You surely do not know that it is perhaps also a piece of my life, yet it is so. It is perhaps more for me. It is pieced together and patched together from the shreds of my self. ${ }^{10}$
\end{abstract}

The earliest recorded expression of Hugo Bergmann's Zionism is this letter to Franz Kafka from 1902. It begins with the repeated 'wondering' of a classmate about why the opening question should be a question for him at all, for his Zionism was inextricably connected to the circle of classmates and their common condition. The positions of Kafka and Bergmann were perhaps not as foreign to one another as they seemed.

Bergmann's Zionism was from the outset constructed in a complex way which can be seen as a model for all that is to come. An 'idée fixe' is in one gesture transformed into something very material in Bergmann's letter, with the awkward and persistent appearance of the term 'piece' (Stück). So adherence to an external ideology here has an immanent source - it is a 'piece' of Bergmann's 'life', with all the ring of authenticity and essentiality that the term Leben had in the early twentieth century. But this 'piece' of life is itself 'pieced' together from 'shreds of self'. This reflexive relation, conflating and then again subdividing subject-predicate definitions, scrambles the terms necessary to construct a simple relation between self and community. And of course that relation is at the heart of the step that Bergmann has taken. The letter continues:

I have searched and searched. . . . I did not have the strength to stand alone, like you. . . . Don't think that it was sympathy that made me a Zionist. My Zion is a good piece of selfishness. I sense that I would like to fly, I would like to create and cannot; I no longer have the strength. And yet I also sense that I might have the strength under other circumstances, that the innate ability doesn't abandon me at all. I only lack the strength.... Perhaps we will in fact overcome this weakness once more, and stand sturdily once more on our own ground instead of waving unrooted like a reed; perhaps, perhaps I will even find my strength again. ... Sometimes I feel that I might be able to fly, but then my strength is broken and my wings are lame. I would like to stand for once on our own ground and not be rootless. Maybe then my strength will return to me, too.

The lamed and powerless modern self, then, seeks a reconstitution of strength through rooting itself in a community. The individual alone is defeated by what Bergmann elsewhere in this letter calls 'raw reality'. However, there is a slippage in the text from the declaration of 'my' loss of strength to 'our' weakness - the strength does not return with inclusion in the community, for the community itself is impotent outside its rootedness to a territory.

The element of strength (Kraft) seems manifestly in step with the Zionism of this period, with its stress on reversing the qualifiers associated with diaspora Jewishness. Despite this similarity, Bergmann does not faithfully reproduce a discourse where positive 'strength', physicality and power are juxtaposed to a

10 Hugo Bergmann to Franz Kafka 1902. Reprinted in part in Shmuel Hugo Bergman, Tagebücher \& Briefe, ed. Miriam Sambursky (Koenigstein/Ts. 1985), vol. 1, 9. 
negated intellect or an ephemeral spiritualism. For what Bergmann seeks in this circle of community, which fast becomes a territory, is the power to dream; it is the strength to stand ground, but only in order to escape from 'raw reality'. This paradox, Bergmann's need to be 'rooted' in order to 'fly', already suggests the extraordinary ambivalence of his relationship to the notion of territory.

Kafka, for his part, might wonder how his lack of faith in a communal circle could be read as an expression of strength. In a more resigned despair over powerlessness, Kafka stands in an open-ended and unstable territory for one, sooner characterized as an angle (Winkel) than as a circle, and writes: 'What have I in common with Jews? I have hardly anything in common with myself and should stand very quietly in a corner [Winkel], content that I can breathe. ${ }^{11}$

The ellision of Bergmann's images of rootedness (to territory) and flight (of spirit) are not merely the mixed metaphors of a confused teen. This creative play with territorial metaphor foreshadows Bergmann's most serious philosophical and political work from his university years until his departure from Prague after the first world war. Implicit in these images is the binary opposition of reality/ideality - an opposition sustained by a set of powerful assumptions which Bergmann's Zionism attacked head-on.

When Bergmann entered university and joined the Zionist student association Bar Kochba in 1901, the organization was ripe for revitalization. In its short history, the Jewish-national student association had not maintained a stable membership nor a consistent programme. ${ }^{12}$ Even in Bergmann's tenure, only a very small minority of Jewish students chose to join Bar Kochba rather than the German-liberal Lese- und Redehalle der deutschen Studenten in Prag. ${ }^{13}$ Yet, Bar Kochba can be said to have represented the focus of Bohemian Zionism in the pre-war period,,$^{14}$ and the birthplace of the stamp of Zionism which was peculiar to Prague. ${ }^{15}$ By all accounts, the original direction Bar

11 Franz Kafka, diary entry, 8 January 1914, Tagebücher in der Fassung der Handschrift, eds Hans-Gerd Koch et al. (New York 1990), 622.

12 Founded in 1893 with the name Maccabäa, the organization went through several changes of name and charter before adopting the name Bar Kochba and an openly Zionist line in 1899. For more detail on the origins and development of the association, see Stuart Borman, The Prague Student Zionist Movement, 1896-1914, doctoral dissertation, University of Chicago 1972.

13 The date of the founding of Maccabäa corresponds to the year that German volkish-minded students broke off from the Halle to form the anti-liberal and antisemitic competitor Germania. It is interesting to note that at the turn of the century, both Germania and Bar Kochba memberships consisted by and large of students from outside Prague. This supports the thesis that the Prague 'island' was out of step with ideology in the Bohemian and Moravian periphery. The Jewishnational association was founded by Russians studying in Prague, and the students responsible for the adoption of a Zionist line were Czech-speaking Prague 'transplants'. See Hillel Kieval, The Making of Czech Jewry: National Conflict and Jewish Society in Bohemia, 1870-1918 (New York and Oxford 1988), 93-8.

14 Ibid., 99.

15 Felix Weltsch speaks significantly of their 'distinctive — though perhaps not a leading — role in the Zionist movement'. 'Realism and Romanticism: Observations on the Jewish Intelligentsia of 
Kochba took in the first years of the twentieth century can be directly attributed to the activity of Hugo Bergmann. What was that direction, how did it engage young Jewish people at the time? A former Bar Kochba member recounts:

At that time, a community was created that took pains to spread the idea of a Judaism of life and of the future.... The realization [Verwirklichung] of Jewish life did not simply serve an externally-directed programme. . . . It stressed the necessity that a member take up Jewish culture in himself. ${ }^{16}$

This passage reads like a catechism, with the terms learned by rote remembered years later by the devoted pupil. The contents of this catechism, the discourse constituted by the elements of 'life', 'future', 'realization', 'external/ internal', and so on, are at the heart of the project the Prague student adherents preferred to call 'cultural Zionism'. ${ }^{17}$

The concrete programme of Bar Kochba was decidedly intellectual; it stressed the study of Hebrew, Jewish history and even Yiddish, while the public social activities typical of most student associations were replaced by public addresses and discussions on Jewish topics. Yet it is important to keep in mind, as the quotation above stresses, that the significance of this programme was not conceived as an externally-directed, didactic one. The activities were designed as a route out of a foreign cultural circle (Kulturkreis) into the circle of Judaism..$^{18}$ This transformation was presented as the solemn, personal task of each member of Bar Kochba, and its ultimate goal was the general cultural regeneration of Judaism. Viktor Freud claims that the students' Jewishness may previously have been represented as an object of 'love' or 'passion', but now took on the urgency of a more active 'task': the realization of Judaism. ${ }^{19}$ Thus Bergmann described the role of Hebrew as specifically non-instrumental, that is, as a key neither to understanding the Bible nor to an aestheticist

Bohemia and Moravia', in: The Jews of Czechoslovakia. Historical Studies and Surveys, vol. 2 (Philadelphia 1971), 440. George Mosse calls the Prague Bar Kochba 'a germinal group in the intellectual history of modern Judaism', implicitly recognizing that their somewhat idiosyncratic position was in another way paradigmatic. See G. Mosse, 'The Influence of the Volkish Idea', op. cit., 82 .

16 Zirkular (Newsletter of the Iggud Vatikei Bar Kochba [Association of Former Members of Bar Kochba], Tel Aviv), April 1967, 4.

17 The term is most often associated with Martin Buber. Giuliano Baioni puts this 'cultural Zionism' at the centre of his description of Kafka's context; see Baioni, Kafka: letteratura ed ebraismo, 3-36.

18 'The efforts of the Zionists to achieve here what is already reality in the East - the creation of Jewish cultural circles [Kulturkreise] — are still in their beginnings', Iwri [Hugo Bergmann], 'Das Babel der Kleinvölker. Prager Brief', Jüdische Zeitung (Vienna), 13 December 1907.

19 'Die unmittelbare Bedeutung des Zionismus bestand darin, daß er zum erstenmal die jüdische Jugend für die jüdische Sache begeisterte, die bis dahin ein Gegenstand der Liebe und des Leidens, nicht des strebende Tuns gewesen war. Jetzt zum ersten Mal wurde von der Jugend verlangt, was ihr Lebenselement ausmacht: Bewährung des Judentums in der Wirklichkeit, Verwirklichung des Judentums. Der Drang, das Judentum im Leben zu verwirklichen, ist die Grundkraft der BarKochba in allen Zeiten gewesen.' Zirkular, January 1967, 3. 
appreciation of its beauty. The 'serious Jew' recognizes that taking Hebrew into him or herself is an 'irrefutable necessity', offering a 'new, swelling life'. ${ }^{20}$

The achievement of Zionist youth in learning Hebrew was no less than the recovery of a continuity in Judaism, represented in two and a half millennia of religious writing. Bergmann's own intensive study of the liturgical canon testifies to its importance in this view of Zionism. The religious texts were seen as the key to Judaism's essential spiritual mission in universal history: from the attack on paganism through the 'Jewish' revolutions of Christianity and Islam, Judaism brings history to the moment of messianic revolution, a transformation of the mature world opened up by the French Revolution. ${ }^{21}$ Bergmann, therefore, could not imagine a Zionism that could be separated from an essential religiousness rooted in scripture - even the impulse of non-believing Jews to go to Palestine must be 'religious'. None of this could be changed by what he identified as Herzl's and Nordau's 'politicization' of Zionism, which attempted to privatize spiritual questions, as in liberalism or socialism. ${ }^{22}$

This spiritual Zionism, influenced by the modern Hebrew essayist, Ahad Ha'am, and especially Martin Buber, who had spoken in Prague in 1903, identified itself in opposition to the 'dogmatic' or 'political' Zionism of Herzl and Nordau — indeed to any tendency that did not seem to spring directly from 'within' the mystical circle of Judaism it sought to create - even as it remained an oppositional camp within Herzl's World Zionist Organization. It should be remembered that the term 'territorialism' in this period referred to another bone of contention dividing Zionists who, after Herzl, sought the establishment of some territory for a Jewish state anywhere on the globe, and those who could not divorce the dream of a territory from the spiritual centre of Palestine. Herzl and the Prague Zionists agreed on Jewish abstention and non-involvement in the Bohemian nationality conflict, but again in different ways, for Herzl's arguments were purely tactical. ${ }^{23}$ The Bar Kochba group eschewed Herzlian tactics for the same reason as it sought to distance itself from the nationality conflict: both represented profane and foreign forms, irrelevant to a spiritualist Jewish renewal. By identifying the necessarily religious, messianic and revolutionary character of Zionism, Bergmann put into question the authenticity of a Zionism based on diplomacy and party politics. Perhaps in doing so, Bergmann and the Bar Kochba seem to have taken an already rigidly defined separation of political and spiritual spheres to radical extremes. On the other hand, such a distinction is hard to grasp within Bergmann's programme itself, which refigures the political rather than dismisses it. His political engagement undermined the secular realm of Jewish

20 'Über die Bedeutung des Hebräischen für die jüdischen Studenten', Unsere Hoffnung (Vienna), vol. 1, no. 3 (June 1904), 85.

21 Hugo Bergmann, 'Religiöser Zionismus', Europäische Revue, vol. 1, no. 12, 370-3.

22 Ibid. It is worth noting that this critical stance toward Herzl and Nordau was conceived to be an oppositional, but still participant, voice within mainstream Zionism. That is, Bergmann and the Bar Kochba remained loyal to the World Zionist Organization dominated by the vision of Zionism they criticized.

23 Theodor Herzl, 'Die Jagd in Böhmen', Die Welt, 5 November 1897. 
'politics', it challenged Zionist youth to join in a spiritual transformation of self which would change the 'political' world. But this strict heavenly diet was predictably not to everyone's taste.

In the year that Bergmann became chairman of Bar Kochba, a group of members proposed that a faction of the association take a more 'fighting' stance in Prague student life: wearing colours, entering duels and taking on the form and function of more typical Austro-German fraternities. In Prague, this included the regular boisterous marching on the boulevard Am Graben, where, upon meeting rival Czech student groups, it predictably turned into fighting. The new group wished to remain a faction within Bar Kochba, which Bergmann and his supporters would not allow. The suggestion that only a section of the circle of Zionists would go in this direction naturally did not appease those committed to his uncompromisable vision. When the dissatisfied students formed their own corporation called Barissia, with the motto 'Wort und Wehr für Judas Ehr', Bergmann insisted on a rule forbidding Bar Kochba members from participation in any of its activities. ${ }^{24}$ The vehemence with which the Bar Kochba leadership rejected Barissia - it even attempted to have it barred from the Austrian and World Zionist Organizations ${ }^{25}$ - emphasizes the fact that Barissia was not merely a rival; it was founded on principles irreconcilably opposed to Bar Kochba's. Years later, with calm retrospect, a cohort of Bergmann concludes that

'Barissia', with a conscious appropriation of foreign forms, fought an outward [nach außen] battle against assimilation in order to more easily win over Jewish society. 'Bar Kochba' searched for the way inward [nach innen]; it immersed itself in the problem of Jewishness .... On the one side a battle for Jewish society to be won over to Zionism, on the other a struggle for Jewish spirituality. ${ }^{26}$

This neat chart of oppositions, which are anything but complementary, could have served as a model for the critique at the heart of the Bar Kochba programme.

Bar Kochba's search for the way inward is related not only to the cultural Zionism of Ahad Ha'am but also to the policy that came to be known as Gegenwartsarbeit, or 'present-work'. ${ }^{27}$ Gegenwartsarbeit was the catchphrase for an activist Zionist policy which focused on conditions of Jewry in the diaspora, a position rejected by the political Zionists. ${ }^{28}$ While it was usually

24 See Borman, Prague Student Zionist Movement, op. cit., 55-75.

25 According to Hugo Brauner, 'Zur Geschichte der Verbindung', Fünfzig Semester 'Barissia' (Prague 1928), quoted in Kieval, Making of Czech Jewry, op. cit., chap. 4, note 95.

26 Viktor Kellner, quoted in Zirkular, January 1967, 3.

27 The programme was introduced at the Conference of Austrian Zionists in 1901 by Berthold Feiwel. See Kieval, Making of Czech Jewry, op. cit., 102. Kieval claims that Feiwel 'may have had the most direct role in Bar Kochba's formulation of Zionism as a "spiritual revolution", and quotes Barbara Kestenberg-Gladstein's agreement in 'Athalot Bar Kochba' in Felix Weltsch (ed.), Prag v'Yerushalayim (Jerusalem 1954), 94.

28 Jonathan Frankel identifies Gegenwartsarbeit as 'revolution in the diaspora', J. Frankel, Prophecy and Politics: Socialism, Nationalism, and the Russian Jews, 1862-1917, 281; also, 319-21. 
associated with the alleviation of conditions of strife in the Pale of Settlement, Bar Kochba stressed the amelioration of the state of cultural destitution of Western Jewry on its home turf.

The proposed re-evaluation of priorities represented a shift of focus from a Zionism oriented outwards, aimed at the establishment of a Jewish state through external means, to the issue of cultural renewal within the Jewish circle. By the time of the Tenth Zionist Congress, it had become clear that early hopes of a quick acquisition of territory via a diplomatic windfall or magnanimous Jewish patronage had been unrealistic. Bergmann declared that this fact returned the focus from Palestine to the work of every small and local Zionist organization; if 'Zionism is Judaism on the road to self-liberation', Bergmann insisted that 'all of us, whether we live in Palestine or here, are on this road. ${ }^{29}$ Jewish Palestine could not redeem world Judaism from without; the Jewish people must first find their homeland in themselves.

If the road to self-liberation must be found within the individual - and yet this search itself is part of a communal gesture with universal consequences the structure of political centre and periphery is necessarily disfigured. Bergmann's use of the centre-periphery model in the reconstruction of these relations has a subversive effect. The ease with which the centre-periphery structure is used to represent ideas that break it apart betrays Bergmann's intimate familiarity with it. We recall the discourse of German (-Jewish) liberalism in Prague, with its self-authorization as the centre of Bohemian culture and politics $;^{30}$ or the marginalization of the Jewish majority of German Prague through the rise of a volkish German circle centred in an Aryan mythology; the currents of ideology and politics which pushed the Prague of Bergmann's parents straight out of the constellation of German cultural spheres revolving around Vienna. The language of centre and periphery was native to the Prague Zionists - they employed it with fluency and undermined it from within.

The spiritual Zionism embraced by Bar Kochba found its revolutionary character in the stance that a movement of self-liberation can only take place within the self. Thus it saw the diplomatic manoeuvres cheered by mainstream Zionists as counter-productive. In his 1913 speech to the Bohemian Zionist District Assembly, Bergmann differentiated Zionism from other Jewish perspectives through its active engagement with Jewish destiny, an engagement that eternally separates slaves from free beings, or those that 'choose' from those that 'let happen'. ${ }^{31}$ Deploying the revolutionary rhetoric of the central European youth of this period, which, as Mosse has pointed out, is as connected to volkish thought as it is to Lebensphilosophie or 'vitalism', Bergmann

29 Bergmann, 'Grösserer Zionismus', in Jawne und Jerusalem. Gesammelte Aufsätze (Berlin 1919, reprint Koenigstein/Ts. 1981 [hereafter JJ]), 7.

30 One example of the revolt of the periphery can be identified in the previously mentioned ' $L O S$ von Prag' ('Free from Prague') movement, where Germans from Northern and Western Bohemia, resenting Prague's anachronistic liberalism, attempted to move the cultural and ideological centre of German Bohemia to Reichenberg (Liberec).

31 The speech is reprinted as 'Die zionistische Kulturarbeit im Westen', JJ, see 14. 
condemned the political Zionist approach for being mechanical - it becomes carried away with the machine of politics and leaves behind the organic, spiritual Jewish Volk. The stress on culture, he explained, was because culture is what is most intrinsically [am innigsten] bound to true Zionism, which is not the instrument of a party (or machine), but the expression of a people [Volk]. A Volk does not have abstract goals, it lives. 'Cultural work' would 'fulfil the Jewish community with real life'. 32

Bar Kochba's programme of lectures and discussions, Hebrew lessons and readings in Jewish history and literature was seen as intimately connected to a revolutionary project to renew modern Judaism. The modernity under attack - mechanical and lifeless - was clearly not unique to the Jewish community; in the rhetoric of the above passage it is impossible to ignore the tones of a particular German-language culture critique running through the late nineteenth and early twentieth centuries. The spiritual leader of the Bar Kochba circle in this attack on the modern Jewish condition, the modern condition par excellence, played an important role in its cultural programme - Martin Buber returned to Prague to speak in 1909.

The relationship of Martin Buber to the Prague Circle of Zionists was, by all accounts, a special one. Bergmann had long been influenced by him, and had invited him as guest speaker to Bar Kochba's first Festabend in 1903. But the real engagement between Bar Kochba and Buber began with a series of three lectures sponsored by Bar Kochba between 1909 and 1911. Max Brod attended the lectures as 'guest and opponent', and came out a Zionist. ${ }^{33}$ Interestingly enough, the experience also left its mark on Buber himself. He found in the young Prague intellectuals a certain attachment, a family resemblance of sorts, ${ }^{34}$ and he was to maintain contact with some of them for the rest of his life. ${ }^{35}$

So it was that, when his lectures were published more or less verbatim,

32 Ibid., 13. The secondary literature on Zionism often refers to the 'cultural controversy' of the early twentieth century as an early theatre of the conflict between secular Zionism and orthodoxy. Beyond the practical question of Zionist educational policy lay the core ideological question of how Jewish culture - indeed, Judaism — was to be defined. Bergmann and the Bar Kochba membership were atypical of German-speaking Jews in their attachment to the cultural question. Herzl's attempts to defer the discussion certainly had a tactical side to them, but he was perhaps not entirely disingenuous (if simultaneously strategic) when he confessed to an assembly of delegates that he did not have the slightest idea of what the 'cultural question' meant. For the best summary see Ehud Luz, trans. Lenn J. Schramm, Parallels Meet: Religion and Nationalism in the Early Zionist Movement (1882-1904) (Philadelphia 1988), 137-58.

33 See Max Brod, Streitbares Leben 1884-1968 (Munich 1960), 67.

34 Hillel Kieval argues convincingly that an 'elective affinity' may have had its roots in Buber's childhood in the multinational and polyglot Austrian Galician Lwów (Lemberg): 'Buber offered in his own person the mirror image of the Prague Zionist. From a corner of the Habsburg monarchy that was nationally ambivalent, yet Jewishly traditional, he had emerged to reaffirm, redefine, and recreate his Jewish national personality.' See Kieval, Making of Czech Jewry, op. cit., 129.

35 See Grete Schaeder (ed.), Martin Buber: Briefwechsel aus sieben Jahrzehnten (Heidelberg 1972). The complete Buber correspondence is found in the Martin Buber Archives, Manuscript Department of the Jewish National and University Library, Jerusalem (MS Var 350). 
Buber admitted his embarrassment, as if some convention of intimacy were being violated:

I hesitated [to publish the lectures], because it remained very much in my mind how they originated: spoken from a Jew to Jews, particularly aimed at a circle of young people, out of the inspiration of the most subjective co-experience, and in a sphere of the most direct response. ${ }^{36}$

Buber is not merely suggesting that his address is tailored to his audience. The receptive 'circle' he describes reduces itself with astonishing velocity, from a macroscopic to a microscopic lens view. Buber remembers his lecture as, first of all, having a general audience, then as a discussion within a national community, next as taking place in a smaller circle of 'young people', not without a suggestion of revolt; ${ }^{37}$ from there Buber enters an even smaller circle, the realm of 'subjective co-experience', the dialogue between subjects, and finally straight into the 'sphere' where direct response is effected, into the subject itself. The structure that is set up in Buber's introductory apology is diagrammatic for the text that follows. His analysis hinges on a rhetorical structure of concentric circles, where an essential conflict can be traced from the heart of a universal crisis to the condition of Judaism, and finally to a struggle within the individual self.

'Why do we call ourselves Jews?' is Buber's framing question in his first lecture, 'Judaism and the Jews'. ${ }^{38}$ It is important to him that the question be defined not as an abstraction, but as something very 'real': 'your actual life ... our actual life'. As in Bergmann's discourse, he stresses that by 'life' he does not mean to refer to 'external machinery', but its 'internal reality'. Judaism has as much meaning for the Jews as it has inner reality. By deploying the singular 'life' with the plural pronouns 'your' ['Ihr'] and then 'our', Buber closes a circle around a collective 'life' which must be defined from within. The inner/ outer dichotomy, implicit in the rhetorical structure of the circle, takes on ethical significance in Buber's essays. We should also note at the outset the character of those terms relegated to the 'inside' - 'Leben', 'essence', 'reality'

36 Martin Buber, Drei Reden über das Judentum (Frankfurt/Main 1916), 7. The first edition was printed in 1911. In spite of the impact which contemporaries insisted the addresses had on this generation of Central European Jews, Buber scholars and others have given them much less attentive readings than, for instance, his later philosophical work, his retelling of Hasidic narratives, or his bible work. See e.g. Maurice Friedman, Martin Buber: The Life of Dialogue (Chicago 1955), 31-3; cf. idem, Martin Buber and the Eternal (New York 1986); Paul Mendes-Flohr and Steven Kepnes, The Text as Thou: Martin Buber's Dialogical Hermeneutics and Narrative Theology (Bloomington, IN 1992).

37 Buber was only five years older than Bergmann, and no more than ten years older than the university students active in Bar Kochba. In the rhetoric of Expressionism as well as that of the volkish nationalist movement, 'youth' takes its place alongside 'renewal' in the battle against a 'decadent' and even 'senile' liberalism.

38 Buber was originally invited to be guest speaker at a Bar Kochba Festabend, open to the public, in January 1909. The stunning reception of the first lecture led to subsequent invitations for Buber's return, which took place in April and December 1910. 
- with their organic connotations, as against an external machinery capable only of abstraction.

So the structure of the question determines the fundamental heresy of an answer which defines Jewishness according to the relationship to the nonJewish [außerjüdischen] world. 'How can [the individual] feel his people not just around him, but inside himself?' ('. . . nicht bloß um sich: daß er es in sich fühlt?'). ${ }^{39}$ The difference is defined by the hostile relation of the prepositions 'um' and 'in', which define a circle from without (around) and within (inside). 'Umwelt' and 'Innenwelt' introduce the list of contents of a dichotomy which is at the centre of Jewish (that is, also universal, and individual) existence - a life-critical choice

. . . between environment and inner world [Umwelt und Innenwelt], between the world of impressions and of substance, between atmosphere and blood, between memory of one's lifespan and memory of millennia, between the purposes presented by society and the task of redeeming one's own power. ${ }^{40}$

The process of personal, communal and universal redemption is the subject of the three lectures. The spiritual dimensions of that organic process do not belong to this part of my discussion, but to the part that follows. Yet, the first step toward the 'sanctification' of the circle is the ritual suggested in the above choice. For the way to redemption is a journey toward unity and toward the destruction of the 'deep schism of existence' described above. 'Judaism and the Jews' defined analogous circles of nation (Buber: 'Menschenkreis') and of the individual subject. Buber's construction of the question of identity itself invites the sanctifying gesture of unity through the replication of the contents within the two analogous circles. It will come to the moment when a Jew will think of his/her people (Volk) and feel:

I don't have compassion with them, but they are my passion. My soul is not with my people, but rather my people is my soul. And in this same sense, every one of us will feel the future of Judaism, and will feel: I want to continue living, I want my future, want a new, whole life, a life for me, for the people within me, for me within my people. ${ }^{41}$

39 Buber, Drei Reden, op. cit., 15.

40 Ibid, 26. Buber's disturbing and frequent use of the term 'blood' - 'the deepest layer' of the self - is not easily overlooked, even if it is always deployed as metaphor. What is interesting about the way the metaphor operates in the text is that it is always associated with 'choice' in a way its volkish counterpart of course could never be. This is not unrelated to Michael Löwy's observation that Buber's radicalism lies in its refusal of a desire for a pre-modern or pre-social (Tönnies) community of blood (Blutverwandtschaft) in favour of a post-social community based on free choice, connected to what Löwy calls 'elective affinities' (Wablverwandtschaften), after Goethe and Weber. See M. Löwy, Rédemption et utopie: Le Judaïsme libertaire en Europe centrale. Une étude d'affinité élective (Paris 1988), 64-5. Notwithstanding, the more sinister 'elective affinity' George Mosse pointed out in his article on volkish thought and this generation of Central European Jewish rhetoric is at least as salient.

41 Buber, Drei Reden, op. cit., 29. 
This vision cannot be reduced to an argument for membership in a national community. Much more is implied in this discursive axis, which sets self and Volk in perfect alignment. The borders of the nation are in turn analogized by the outline of the body, circumscribing the self. It is within this single circle that the question of personal Jewish identity coincides with the 'Jewish Question'.42

Buber's internal identity issue is closer to the externally-defined 'Judenfrage' than it appears. The relation of the Jewish self and community to the larger circle, the analogy of the crisis in Judaism to the crisis of modernity, is made explicit in Buber's second lecture, 'Judaism and Mankind'. Having established that Judaism is above all a 'polar phenomenon', defined by its inherent sets of oppositions, Buber moves easily to the claim that the Jew has an extreme and unique 'duality consciousness'. The struggle of Judaism in all of its creative periods has been the striving toward unity: unity within the individual, of the people, among peoples, between humanity and other living things, and finally between God and the world. ${ }^{43}$ The privileged position of Judaism with regard to the redemption of humanity is based on its privileged relation to that from which humanity must be redeemed: the will to unity is bred into Judaism because of its inbred dualistic and fragmented nature. If Judaism is to save mankind from degeneration, it is because degeneration is essential to Judaism. ${ }^{44}$ This is the dark secret behind Buber's promise of a mystical coincidence of redemption fixing together the circles of the self, Judaism and humanity.

And so this is and remains the basic significance of Judaism for mankind. Aware as no other in its innermost being of this original dualism, knowing it and representing it as no other, that it proclaims a world from which it is expelled: a world of God, which wants to be realised in the life of the individual as well as in the life of the whole: the world of Unity. ${ }^{45}$

The aspect of purification (Reinigung) within Judaism is therefore a fundamental element within the promise of Buber's third lecture, 'The Renewal of Judaism'. Unity is one of three ideas whose realization stands at the centre of the historical mission of Judaism; it is the idea that characterizes the goal of that mission. The other two ideas - 'Deed' (Tat) and 'Future' (Zukunft) emphasize the revolutionary germ which activates the periodic 'renewal' of the unifying mission. The three ideas are not 'abstract concepts', but on the contrary, 'natural tendencies' in Judaism which must be realized. A unification of spirit and matter is already implicit, then, in what is defined as a spiritual struggle for reification. ${ }^{46}$ For the degeneration within Judaism is actually the

42 Ibid., 27: 'This is what I call the personal Jewish Question, the root of all Jewish Questions, the question that we find in ourselves, and which we must decide within ourselves.'

43 Ibid., 44.

44 Ibid., 29-30. Degeneration in the sense expanded upon by Max Nordau is directly called upon and identified as the mark of contemporary Judaism, from which the coming Jewish generations must be liberated.

45 Ibid., 56.

46 Ibid., 74. 
impurity of the Jewish circle - the confusion of the outside with the inside, the projection of foreign forms onto native essences. The circumscription of a purified and discrete territory for Judaism in itself begins a process of activation of the natural tendencies Unity, Future and Deed.

This more purely Jewish sphere is a place where concepts take on a character which Hugo Bergmann describes as 'fundamentally distinct from [those] known to us through the conceptual world of our cultural circle [Kulturkreis]'. ${ }^{47}$ So it was that in the lectures sponsored by Bar Kochba, Martin Buber inscribed an imaginative space reserved for authentic Judaism. The circle of young Prague Jews listened, and thought of how they could occupy that space and make it holy.

\section{Sanctification}

The fusion of spirit and matter is the task of Judaism that Bergmann finds in the strange $^{48}$ notion called 'Kiddush Hashem', 'the sanctification of the name'. Clearly in this term, which Bergmann chooses for the title of what will become his most important essay on Judaism, one can identify an active process intended to spiritualize ('sanctify') matter ('name'). But the 'strangeness' of this concept lies in its reversal of the valences of a simple spirit-matter (or 'heaven and earth') dichotomy, where the deity is not holy in and of itself, but is made holy by the human act: 'Neither shall ye profane my holy name; but I will be hallowed among the children of Israel: I am the Lord which hallow you. ${ }^{99}$

The circle of Judaism is not, then, merely a physical community chosen and blessed from an external spiritual realm - it is in the centre of this circle 'among the Israelites': 'in der Mitte der Kinder Israels') that God is hallowed. Bergmann accepts Buber's proposition that a certain fundamental dualism is essential in Judaism; the dualism, however, like the conception of the relationship between creator and creation, is astonishingly dynamic.

We will take the wind out of Bergmann's sails by revealing where his biblical exegesis leads: the Jewish deed (or 'act') is set up as eternally bound to this law of holiness, so that even compromise, fragmentation, assimilation and opportunism all become 'covered by the Holy Name'. That is, God is not sanctified in the middle of the children of Israel, but profaned within an impure circle. The old sense and function of the term can only be recovered by a Buberian renewal of Judaism - 'Zionism is our Kiddush Hashem'.

This somewhat undramatic disclosure of Bergmann's argument has the advantage of allowing us to focus on what is more remarkable in the essay: for the 'dynamism' Bergmann sees in the Jewish conception of God soon consumes a whole discourse which has been based on the existence of an inexorable dichotomy. The concept of God itself no longer stands unequivocally on the side of heaven - in the declaration 'YHWH Elohim' Bergmann

47 Hugo Bergmann, 'Die Heiligung des Namens' in Verein Jüdischer Hochschüler Bar Kochba in Prag (ed.), Vom Judentum: Ein Sammelbuch (Leipzig 1913), 33.

48 Ibid.

49 Leviticus 22:32. 
sees a union of the principle of creation (in 'Elohim' or God) and the divine sustainer of the world (in Jehovah, the true name); in 'Elohim' itself he sees the manifest 'elh' ('this') combined with the unsubstantiated subject of the world 'mi' ('who'); finally, in the principle of the 'name' itself, with its various layers, Bergmann loses track completely. In despair, he writes to Buber:

The concept 'Name' is hard. In my lecture I thought it could be understood as the expression of God comprehended as object. Then the true name would be the God which is spoken of by the non-God-united, the God still merely conceived from without, but not realised within. ... In as much as we speak of God, we do not actually speak of him, but rather of the Name. Perhaps that would explain why the High Priest on Yom Kippur, standing to a certain degree in Unity, calls on God with his real name, whereas the congregation answers merely: Baruch shem [Blessed the Name]. The true Name, that is YHWH, and the germ which must be reified ('sanctified', 'unified') in order to become YHWH. But then as to what could be meant by the difference between God and his true Name, for example when it is said that before creation only God and his Name existed, I am completely at a loss. ${ }^{50}$

This dense passage discloses a complex field of relations effected by a dynamic and mystical view, where terms weave in and out of the spirit-matter dichotomy, rather than being shuttled into place under a rigid binary structure. The earthly community is divided (into those 'united' with God and those comprehending Him from 'without'); the division 'God' and 'the Name of God' is undermined by further divisions: the spiritual 'true Name' (YHWH) against the material 'Name' (Shem), recalling the former duplicity of a subjectGod, who sanctifies, and an object-God, to be sanctified.

A key to the puzzle of these alternations is found in the parenthetical clarification claiming synonymous status for the terms 'reified', 'sanctified' and 'unified'. It is symptomatic of Bergmann's elastic categories that the material Name must be made 'real' (verwirklicht) to cross over into the realm of the spiritual. The earthly and the divine become one in the charged space between these two worlds, exactly where the firmament defining the dichotomy used to exist. The effect of this rhetorical cross-dressing is to jumble the original rhetorical edifice to a point where the speaker can call upon terms such as 'real', 'politics', 'Zionism', to define a programme which could also be described by the terms 'holy,' 'faith', and 'humanity'.

Looking back, the seeds of this gesture are detectable in Buber's original lectures, where the dualism structure, as something by definition unwhole, stands on one side of itself. While an exhaustingly long 'present' has been characterized by schism, the primal past and the messianic future are whole. To Bergmann's confused question about the primal existence of the dual 'God and His Name', Buber responds that

... as long as Unity is conceived not as a goal, but as an origin, it can no longer be conceived as pure unity. For we can all comprehend the creative function merely as polarization, as the expression of an immanent duality. ${ }^{51}$

50 Letter from Hugo Bergmann to Martin Buber, 2 May 1913. Martin Buber: Briefwechsel aus Sieben Jahrsehnten, op. cit., 329-30.

51 Martin Buber to Hugo Bergmann, 7 May 1913. Buber Briefwechsel, 331. 
Buber finds it significant that the Oneness over all disunity, God, is continually penetrated (wird durchsetzt) with duality. The use of the passive voice here raises the question of the source and motive behind this dichotomization. The isolation of spiritual from material life served an ideological function in diasporic Judaism: it justified the maintenance of spiritual, confessional and moral authenticity discrete from the profane realm of physical life 'among the nations' ${ }^{52}$ It is in this context that Bergmann's project to reassemble the dualistic structure in a way that caused it to consume itself must be read.

While Buber may have exerted the most direct influence on Bar Kochba Zionism before the war, Ahad Ha'am always stood as a towering figure in the minds of its members. Judging from Bergmann's allusions to him - he was the subject of very early Bergmann lectures - it is unlikely that his influence came to Bar Kochba only through the mediation of Buber or Berthold Feiwel. Asher Ginsberg (alias Ahad Ha'am) was after all the Zionist thinker who dwelled upon the dichotomy of spirit and territory as a central problem of Zionism and of historical Judaism.. ${ }^{53}$ One of Ahad Ha'am's best-known essays is the 1904 piece entitled 'Moses', which appears of greater general interest than most because it does not engage as directly with the minutiae of intra-Zionist polemics. ${ }^{54}$ It was very likely this essay that inspired Bergmann to undertake the edition of the volume Worte Mosis in the Bruns' Verlag series Die Weisheit der Völker. ${ }^{55}$ Among Bergmann's pre-war writing on Jewish subjects, this work is largely overlooked, appearing to diverge from his programmatic Zionist essays. It was with the vehicle of the figure of Moses, then, that both Ahad Ha'am and Hugo Bergmann were able to cloak their deeply polemical projects in the garments of quasi-biblical scholarship. ${ }^{56}$

Both Ahad Ha'am and, quoting him, Bergmann, begin their pieces by

52 This strategy of the Jewish bourgeois is analogous to the segregation strategy which Georg Lukács identified in fin-de-siècle aestheticism: he related the strict, narrow, 'ascetic' life of the bourgeois to the programme 'l'art pour l'art' and the attempt to create an unpolluted aesthetic sphere. See the 1909 essay on Theodor Storm in Die Seele und die Formen. Essays (Berlin 1911), reprint Neuwied and Berlin 1971, 82-116.

53 See Shlomo Avineri, The Making of Modern Zionism: The Intellectual Origins of the Jewish State (New York 1981), 112-24.

54 The original Hebrew essay which Bergmann used appeared in Ha-Shiloah, 13 (1904). The German translation in the same year appearing in Ost und West suffers unfortunately from abridgement. An unabridged translation into English appears in Leon Simon (ed.), Ahad Ha-am, Essays - Letters - Memoirs (Oxford 1946), in the East and West Library's Philosophia Judaica series edited by Hugo Bergmann. Another complete translation was published in Leon Simon (ed.), Selected Essays by Ahad Ha-am (Philadelphia 1936).

55 Hugo Bergmann, Worte Mosis (Minden, Westphalia 1913).

56 Bergmann was more explicit about the contemporary analogy in the essay 'Pessach und die Menschen unserer Zeit', JJ, 75-80. The essay is dated 1913 and probably derives from his lecture 'Moses und die Gegenwart'. While it is tempting to compare Martin Buber's study of Moses with those by Ahad Ha'am and Bergmann, Buber's Moses was written much later, completed in 1944, and self-consciously genealogizes itself within a tradition of biblical scholarship rather than these polemic pieces he knew well. See Buber, Moses (Heidelberg 1952). A popular survey of the changing representations of the figure of Moses is offered by Daniel Jeremy Silver, Images of Moses (New York 1982). 
reminding the reader that the attribution of any work to Moses has been called into question, indeed that his actual existence cannot be proven. There is a discordance between historical 'facts' (set by the authors inside disdainful quotation marks) and the 'historical reality of the ideal Moses ... this ideal figure is a creation of the Jewish spirit; and the creator creates in his own image.' Constructed in the form of a defence against positivist historical criticism, these introductory paragraphs do two things: they call into question pedestrian notions of immutable 'reality' and unreal myth, and they equate the figure of Moses with the essence of Judaism. The latter moves serve to privilege the Moses commentator in the broad field of Jewish debate. In a recent monograph on Ahad Ha'am, Stephen Zipperstein points to this special status of the Moses figure, often a symbol of 'decency, righteousness, justice and self-sacrifice'. ${ }^{57}$ Thus Ahad Ha'am's first question, posed as an enquiry into 'what type of man' Moses was imagined to be, contains the seeds of a political programme. Answering in the negative the possibilities of judging Moses' seminal role to have been as warrior, statesman or lawgiver, he finds in scripture the answer that he was in fact a prophet, and more than that, the master of prophets, the symbol of Hebrew prophesy. The prophet in the Jewish tradition is first of all a speaker of truth, secondly an uncompromising 'extremist', wholly fixated on his ideal, and finally the figure incarnating the idea of justice, the realization of truth. These characteristics set the prophet apart from the world; his word can only reach the masses through priestly intermediaries. It is by this process that the spiritual can give impulse to the material (or the 'ideal' to the 'real').

At its most creative and sincere moments, Ahad Ha'am writes, the People of the Prophets see the truth and act upon it, accepting sacrifice, rejecting compromise, without hesitation. And even when Judaism has seemed furthest from these ideals, the Mosaic spark has reappeared to endow it with new life. In 'Moses', Ahad Ha'am self-consciously casts himself as the prophet of a slavish generation of world Jewry. Following him, Bergmann not only works from Ahad Ha'am's basic premises, but identifies himself in the role of the prophet as well. This focus on prophesy underscores the element of future, which Ahad Ha'am as well as Buber saw as central to the eternal mission of Judaism. The prophet is not so much a foreseer of the future as he is its agent, in a present which is to him unbearable and unreal. The dwellers in the present are the masses, for whom the prophetic future and the inspirational past are equally remote. Of course, the future which takes form in the space cleared by Buber's Addresses is above all qualified by wholeness and unity.

The issue of unity is present even in Bergmann's reiteration of Ahad Ha'am's discussion of the authorship of the Pentateuch and existence of Moses. ${ }^{58}$ Following Buber, Bergmann claims that it is 'unity' itself which is the theme of

57 Joshua Eisenstadt Barzilai quoted in Steven J. Zipperstein, Elusive Prophet: Ahad Ha'am and the Origins of Zionism (Berkeley/Los Angeles 1993), 42. Thus the Zionist 'fraternal society' formed with Ahad Ha'am in 1889 was named 'Benei Moshe'.

58 Bergmann, Worte Mosis, op. cit., 3. 
the Pentateuch and the heart of the Jewish religion. At issue in the Exodus is above all the unity of the community. Bergmann's retelling of the story is the struggle between the faith of the prophet and the indecisiveness of the masses, who demand miracle after miracle, who doubt his word and his God, and who repeatedly voice the idea of returning to Egyptian slavery. The struggle of the prophet in the desert between the Egypt of servitude and the promised land of freedom is an internal struggle. The future is blocked by the slavish elements of the community, the community is divided into two hostile camps:

\footnotetext{
'May he who stands with God come to me!' This war cry, which was - and is — called to split the whole world for all time into two camps, resounds first from [Moses'] mouth. And those that come together about him are sent out by the prophet: 'Gird your swords and go through the camp from gate to gate and slay all, brothers, friends, and relatives. ${ }^{59}$
}

The internal struggle against slavishness, indecisiveness and fragmentation is repeatedly brought into the present by such qualifiers as the 'and is' above. The trek from slavery to freedom is a violent one, the negative elements must be rooted out (ausrotten), if slavish nature is not to overcome those on the side of God. And did not even Moses waver, 'as many more prophets after him wavered and as we all waver, when the divine speaks to us'? $?^{60}$ For the struggle in the desert is not just within the community, but within each individual. The spiritual mission of Moses and Judaism aims to make whole on the levels of humanity, the community and the disunified or undecided subject.

In this way, the potential role of the prophet taken on by Bergmann becomes projected onto the reader, who must also decide between 'choosing' and 'letting happen'. While the correct decision seems clear, Bergmann continuously returns to the wavering of Moses himself, to the repeated crises of the 'liberated' people in the desert, the impossibility of the purity and permanency of the choice to liberate oneself. Bergmann's text presents the messianic hope of freedom always coupled with a certain pessimism, as if, despite the gesture of the will to freedom, one may not be sure of emerging from the desert in one's own generation. Franz Kafka, upon hearing his old schoolmate's lecture 'Moses and the Present', was impressed, and yet concluded:

In any case, I have nothing to do with it. The truly horrible paths between freedom and slavery cross each other without a guide for the way ahead and with the immediate dissolution of the paths behind. There are innumerable such paths, or only one, it cannot be determined, for there is nowhere to see them from. There am I. I cannot get away. I have nothing to complain about. I do not suffer excessively, since I do not suffer constantly, it doesn't pile up - at least I do not feel it all the time, and the degree of my suffering is far less than it perhaps ought to be. ${ }^{61}$

Bergmann's presentation of a choice between slavery and freedom has this

59 Ibid., 27.

60 Ibid., 11.

61 Kafka, Tagebücher, op. cit., 17 December 1913, 616. 
pain behind it: the modern self, for Bergmann as much as for Kafka, finds itself neither in Egypt nor in the promised land, but in the uncharted desert between the two. In the last analysis, Bergmann's assumption that one forges a path to freedom not alone, but as part of the community, does not make the trek any easier, since the internal struggle against slavishness and the pain of selfliberation, the 'despair' over territory left behind and not yet found, is located within the self.

Bergmann's project in the edition of Worte Mosis and the Passover essay and lecture, all in 1913, provide an explication of the kinship of the European spiritual crisis of the present to the Jewish historical past, and, with it, to the Zionist vision of the future. Zionism belongs to

. . . the spiritual movement of our time. . . . If one were to try to represent the movement called Jewish Zionism in its universal [allmenschlichen] significance, perhaps one would do best to describe it as a striving for the renewal of humanity through the spirit. It is clear in this definition what the signature of these times is, of the times in which we live and against which we fight: the anti-spirit [der Ungeist], materialism in the broadest sense of the word. ${ }^{62}$

I will risk overstating this point because it is the kind of point that one tends to overlook, or to incorporate into a compromised form which is more familiar and seems more consistent. The Zionism here described, taken from Ahad Ha'am and Martin Buber and fired in the crucible of Prague identity, is not 'also' spiritual, nor 'primarily' spiritual, but spiritual in its definition defined as the movement established to struggle against matter, to expel the concept of territory from its midst. The revolution of Moses, the revolution of the 'liberating deed', is above all an internal struggle to leave slavish materiality behind in the land of slavery.

The striking ambivalence of these texts highlights the painful confrontation between the most radical and creative forms of cultural Zionism and Zionism's basic tenets, which have to include a stress on the issue of physical territory in some sense. Bergmann did hold on to the idea of territory in Palestine as Ahad Ha'am's 'spiritual centre' of the circle of Jewry, 'in some way or another' ${ }^{63}$ But throughout his essays, and in the policy of Gegenwartsarbeit and its justification, Bergmann stressed the dangers of ignoring the periphery, of assuming the importance of the centre to be greater and that the existence of a centre would even (necessarily or automatically) affect Judaism in exile. To the pessimist Brenner's claim that 'Galut [exile] is everywhere', even in Palestine, Bergmann merely adds the corollary, 'Everywhere can Galut be overcome' ${ }^{64}$ It is in this context that we must understand the goals of the Zionist cultural programme Bergmann insisted on implementing in the west:

62 'Pessach und die Menschen unserer Zeit', JJ, op. cit., 75.

63 See 'Ein Schwarzseher', JJ, op. cit., 66.

64 Ibid. 
'We want to get out of the Galut, even while we remain in it physically. ${ }^{95}$ In the ritually repeated inscription of a spiritual territory in Bergmann's texts, there is an implicit flight from the concept of 'territory' itself.

So was Jerusalem in the hearts of the slaves in Egypt, was freedom to be found without setting foot in the promised land? It is in the last chapter of the Pentateuch that the Lord shows the Prophet the whole land, saying, 'I have let you see it with your own eyes, but you shall not cross over into it.' The citation lends itself well to the binary engaged by cultural Zionism, with the segregation of vision or insight from afar in the primary clause, and the physical step onto territory in the second. From Odessa, Ahad Ha'am explains that there is no place for Moses in the Holy Land; the purely spiritual prophet can have no role in the necessarily profane confrontation with physical territory. From Prague, Bergmann's complementary interpretation is that the physical conquest of the land is not what is decisive, rather the victory or defeat of the spirit - the Prophet has succeeded in creating a spiritual territory to be the home of the people of religion, the bearers of the religious idea.

Nearly 80 years after Ahad Ha'am's prophetic essay on prophesy, Amos Oz rides through Samaria, studying 'the elusive cunning of the Biblical charm of this landscape'. ${ }^{66} \mathrm{He}$, too, finds it fitting to recall Moses on Mount Nebo, and to wonder what becomes of sacred territory when it is set foot upon, if it is no longer yearned for by the Jewish spirit, but possessed. Ahad Ha'am left Russia not for Palestine, but for London, where he remained until moving to Tel Aviv in his sixties. Hugo Bergmann also made his way to London, where he served as Secretary of the Department of Culture of the Zionist Organization before arriving in Jerusalem in May 1920.

Indeed, the view of the Holy Land from 'far off' in Prague was a completely separate and contradictory experience from that of 'crossing over' into it. In the short time from the outbreak of war until the journey to Palestine, that vision dissipated, even the memory of the sense of it seemed to dissolve. It was in the first decade of his residence in Jerusalem that Bergmann, now Shmuel Hugo Bergman, wrote on the occasion of the 50th semester anniversary of the old rival organization Barissia, with the ideological barriers between the groups already forgotten:

On this day in which Barissia celebrates its 50th semester, we alumni of Bar Kochba and Barissia should recognise the great error we committed as students: we thought that we could create a Jewish content in our lives through lectures, discussions, and activities. So we splashed around in the shallowness of the so-called Jewish Renaissance and grew into Jews without substance: Am Ha'aretzim. ${ }^{67}$

65 'Die zionistische Kulturarbeit im Westen', JJ, op. cit., 15.

66 Amos Oz, In the Land of Israel, trans. by Maurice Goldberg-Bartura (London 1983), 121-2.

67 From an article of unknown origin, dated May 1928, clipping in file 10a, Shmuel Hugo Bergman Archives (Arc. 4. 1502)/Manuscript Department of the Jewish National and University Library, Jerusalem. 
Barissia and Bar Kochba are on the same side of the duality now, on the side of useless chat in exile, with no real relationship to Judaism. On the other side stands heavy substance, depth, 'reality', only reachable in the centre of Zionism. As if to put a final nail in the coffin of the innovative alternative discourse he did so much to develop as a youth, or else as an unknowing landmark of how far he had strayed, Bergman describes himself and his youthful cohorts as foolish and out of touch, ironically deploying the Hebrew term Am Ha'aretzim, 'people of the land'. In a letter of 1923 to Robert Weltsch, Bergman openly doubts the value of all of the activities of Bar Kochba and calls the Central European Zionism of Buber 'senseless'. ${ }^{68}$ Finally, in an apologetic preface to a late reprint of his famous essay on the Kiddush Hashem, Bergman explains: 'I was young then, did not know real [das wirkliche] life yet and did not know how difficult it is to sanctify God, particularly in political life.' But he penned these words in his eighty-fourth year, in 1967, when he had probably forgotten whether or not the young Bergmann knew how impossible that was.

Scott Spector

is Assistant Professor of History and German Studies at the University of Michigan. He is the author of articles on European cultural and intellectual history, historiography and German film and of a forthcoming book on culture and ideology in fin-de-siècle German-Jewish Prague, Prague Territories.

68 See the manuscript 'Robert Weltsch und Hugo Bergman. Eine Freundschaft aus der Zeit des jungen Zionismus', by Escha Bergmann, Shmuel Hugo Bergman Archives, Manuscript Department of the Jewish National and University Library, Jerusalem, file 136b, Arc. 4. 1502. The Bergmann-Robert Weltsch correspondence is found in the same archive, file 1334, folders 1-11. 